\title{
Anemia and Its Association With Clinical Outcome in Heart Failure Patients Undergoing Cardiac Resynchronization Therapy
}

\section{Citation}

Venkateswaran, Ramkumar. 2017. Anemia and Its Association With Clinical Outcome in Heart Failure Patients Undergoing Cardiac Resynchronization Therapy. Doctoral dissertation, Harvard Medical School.

\section{Permanent link}

http://nrs.harvard.edu/urn-3:HUL.InstRepos:40621367

\section{Terms of Use}

This article was downloaded from Harvard University's DASH repository, and is made available under the terms and conditions applicable to Other Posted Material, as set forth at http:// nrs.harvard.edu/urn-3:HUL.InstRepos:dash.current.terms-of-use\#LAA

\section{Share Your Story}

The Harvard community has made this article openly available. Please share how this access benefits you. Submit a story. 
Scholarly Report submitted in partial fulfillment of the MD Degree at Harvard Medical School

Date: 1 August 2016

Student Name: Ramkumar Venkteswaran ${ }^{1}$

Scholarly Report Title: Anemia and its association with clinical outcome in heart failure patients undergoing cardiac resynchronization therapy.

Mentor Name(s) and Affiliations: Jagmeet P. Singh (MD, DPhil) $)^{2}$

\section{Collaborators, with Affiliations:}

Carolyn Freeman ${ }^{2}$, Neal Chatterjee (MD) ${ }^{2}$ Jagdesh Kandala (MD) ${ }^{2}$, Mary Orencole (MS, ANP) ${ }^{2}$, Eszter M. Vegh $(M D)^{2}$, Kimberly A. Parks $(D O)^{2}$, Peter J. Cowburn $(M D, F R C P)^{3}$, G. William Dec $(M D)^{1,2}$, Jagmeet P. Singh (MD, DPhil) ${ }^{2}$, and Rasmus Borgquist (MD, PhD $)^{2,4}$

${ }^{1}$ Harvard Medical School, Boston, USA

${ }^{2}$ Massachusetts General Hospital, Cardiology Division, Boston, USA

${ }^{3}$ University Hospital Southampton NHS Foundation Trust, Southampton, UK

${ }^{4}$ Lund University, Arrhythmia Clinic, Skane University Hospital, Lund, Sweden 


\section{Abstract}

TITLE: Anemia and its association with clinical outcome in heart failure patients undergoing cardiac resynchronization therapy.

Venkateswaran RV, Freeman C, Chatterjee N, Kandala J, Orencole M, Vegh EM, Parks KA, Cowburn PJ, Dec GW, Singh JP, Borgquist R.

\section{PURPOSE:}

Although a substantial proportion of patients with heart failure (HF) have anemia, there is a paucity of data evaluating the impact of anemia on clinical outcome in CRT patients. Our goal was to examine the ability of baseline hemoglobin $(\mathrm{Hb})$ level and change in $\mathrm{Hb}$ level over time to predict clinical 2-year outcome and echocardiographic response to CRT.

\section{METHODS:}

Three hundred consecutive CRT patients (median 72 years [interquartile range (IQR) 16 years], 19\% female) with baseline and follow-up hematological profiles available were examined.

Baseline anemia was defined as $\mathrm{Hb}<12 \mathrm{~g} / \mathrm{dL}$ in women and $<13 \mathrm{~g} / \mathrm{dL}$ in men, and patients were grouped into equal quartiles based on change in $\mathrm{Hb}$. Two-year clinical outcome was determined using a composite endpoint that included HF hospitalization, left ventricular assist device (LVAD) placement, heart transplantation, and all-cause mortality. Echocardiographic reverse remodeling was examined at 6-month follow-up.

\section{RESULTS:}

One hundred fifty-one anemic patients were compared to 149 non-anemic patients. Changes in left ventricular dimensions and ejection fraction were similar for both groups. Univariate predictors of 2year clinical outcome included baseline creatinine level, diuretic usage, and anemia; in multivariable regression, baseline anemia was an independent predictor for outcome (hazard ratio [HR] 1.79, 95\% confidence interval $[\mathrm{Cl}][1.22-2.63], \mathrm{p}=0.003)$. The quartile with the most negative change in $\mathrm{Hb}$ concentration over time $(\leq-1.00 \mathrm{~g} / \mathrm{dL}$ ) had poorer event-free 2-year survival (HR 1.84, Cl [1.13-3.00], $p=0.014)$.

\section{CONCLUSIONS:}


Baseline anemia and early postimplantation decline in $\mathrm{Hb}$ levels are associated with a worse 2-year prognosis in CRT patients, even though the magnitude of left ventricular reverse remodeling is similar compared to non-anemic patients. 


\section{Student Role in Work:}

I was first author on this publication. Initially, this project was started by a visiting student from the United Kingdom (Carolyn Freeman) the summer before I started working with Dr. Singh. However, none of her data analyses were used because we changed our independent variable (changed our definition of anemia to a gender-based definition of anemia). Thus, I started from scratch with the initial data set. With Dr. Borgquist's help, I analyzed all our data (baseline characteristics, Cox regressions, multivariable analysis). I also wrote the entire manuscript with the primary assistance of Dr. Borgquist and Dr. Singh. Carolyn Freeman specifically helped with the initial literature review, upon which I expanded. All the other authors critically analyzed the manuscript throughout its development and provided feedback and suggestions that were incorporated. I also was the primary person to coordinate by email with all the authors, format the manuscript and images for submission, and eventually submit the manuscript. With Dr. Borgquist and Dr. Singh's mentorship, I also navigated the peer-review process, making numerous changes and running additional analyses to improve the manuscript before it was accepted for publication. I truly learned a lot from the entire process.

Link to Publication: http://www.ncbi.nlm.nih.gov/pubmed/26453528

\section{Citation:}

Venkateswaran RV, Freeman C, Chatterjee N, et al. Anemia and its association with clinical outcome in heart failure patients undergoing cardiac resynchronization therapy. J Interv Card Electrophysiol. 2015;44(3):297-304. 